\title{
The Creationist and the Sociobiologist: Two Stories About Illiberal Education
}

\author{
Illiberal EduCATion. By Dinesh D'Souza. $\dagger$
}

Reviewed by Phillip E. Johnson $\ddagger$

There is a nad reductionisin at work [in the universities]. God is not a proper topic for discussion, but "lesbian pohtics" is. . . In the famous "niarketplace of ideas," where all ideas are equal and where there nuust be no "value judgments" and therefore no values, certain ideas are simply excluded, and woe to those who espouse then1. ${ }^{1}$

In a liberal culture, it is a great rhetorical advantage to appear in a dispute as the champion of free speech against the forces of repression. The left has held this advantage for a long time. The student revolt of the 1960s opened with a "Free Speech Movement," and the bumper sticker that directs us to "Question Authority" imples that the left's politics is a inatter of raising questions rather than imposing answers. Recently, however, academic traditionalists like Dinesh D'Souza have seized the inoral high ground by describing a left-imposed atinosphere of "political correctness" in the universities that leads to "illiberal education." In effect, they have captured the buinper sticker and turned its message around.

The "PC left" under attack is post-Marxist, and its philosophy is post-Modernist. A brief pause for definitions is necessary. In postMarxism, racial minorities, fernmists, and gays have assumed the mantle of the proletariat; the oppressor class is heterosexist white males rather than the bourgeoisie; and the struggle is for control of the terms of discourse rather than the means of production. Post-Modernisin challenges the objective validity of academic traditions by starting from the premise that knowledge coines in texts whose meaning and value are determined by cominurities of interpreters. According to certain cultural critics (post-Liberals?), post-Modern nihihism and post-Marxist political fanati-

$\dagger$ B.A. 1983, Dartmouth College.

$\ddagger$ Jefferson E. Peyser Professor of Law, Boalt Hall School of Law, University of California, Berkeley. A.B. 1961, Harvard University; J.D. 1965, University of Chicago Law School.

1. Page Smith, Killing the Spirtr: Higher Education in America 5 (1990). Page Smith, the author of a famous multivolume history of the United States, retired in 1974 from his professorship at the University of California at Santa Cruz. He is one of many persons, formerly regarded as very liberal critics of American society and its universities, whose voice sounds conservative in today's atmosphere. 
cism have combined to create a university atmosphere that is both antiintellectual and intolerant.

A successful arguinent is not one that convinces everybody, because that never happens, but one that captures the terms of a debate and places opponents on the defensive. Judged by this standard, Dinesh D'Souza has been spectacularly successful. It is not only that approving reviews have appeared froin prominent writers and journals usually identified with left or hiberal pohitics-including Eugene Genovese in The New Republic ${ }^{2}$ and C. Vann Woodward in The New York Review of Books. ${ }^{3}$ More important, the trend-setting media have taken up the debate in D'Souza's terms. The ultimate endorsement came in June 1991, when The MacNeil/Lehrer NewsHour featured an entire week of "conversations about pohtical correctness," with the title "The Big Chill.",

Of course, the left has tried hard to take back the rhetorical initiative. Duke Umiversity law professor Katharme Bartlett stated the inain objections to D'Souza's thesis succinctly in the Wall Street Journal. ${ }^{5}$ Bartlett's institutional identification is important, because the English Department at Duke is a famous center of post-Modernism. Duke's Stanley Fish, a hterary critic who also has a law school appointment, is one of the 1najor villams of D'Souza's book. Rebuttal froin a feminist scholar with personal knowledge of the situation at Duke was thus particularly appropriate.

The academic traditionalists are still firmly in charge at Duke as elsewhere, wrote Bartlett, and Shakespeare and Milton are being taught as before. The critics froin the multiculturalist left are not politicizing the curriculum; rather, they are exposing a long-standing political bias that previously was unquestioned. According to Bartlett, the traditional pohtical philosophy course that begins with Aristotle and ends with John Rawls is just as pohtically loaded as the new alternative offerings in feminist theory or ethnic studies. The only difference is that the bias inherent in the "western civilization" courses went unrecognized because it reflected the dominant (Eurocentric male) point of view. ${ }^{6}$

Bartlett reclaimed title to that "Question Authority" bumper sticker for the nulticulturahists. As she put it, those who have been labelled "PC" "are not trying to stifle debate. We are trying to begin one-a

2. See Eugene D. Genovese, Heresy, Yes-Sensitivity, No, THE New Republic, Apr. 15, 1991, at 30. 32.

3. See C. Vann Woodward, Freedom \& the Universities, N.Y. Rev. Books, July 18, 1991, at

4. The MacNeil/Lehrer NewsHour: The Big Chill (PBS television broadcast, June 17-21, 1991) (transcripts Nos. 4056-4060), available in LEXIS, Nexis Library, SCRIPT File.

5. See Katharine T. Bartlett, Some Factual Correctness About Political Correctness, WALL ST. J., June 6, 1991, at A19.

6. See id. 
difficult one that challenges perspectives that are taken for granted in the university and in society." 7 The traditionalists, on the other hand, are using the PC charge as a "snioke screen" to avoid "a genuine debate ... about acadenic quality and diversity." 8 Their exaggerated complaints about violations of academic freedoin are a strategy to "shield themselves froin criticism of classroon remarks that some students find racist or sexist."

My purpose in this Review Essay is not to evaluate Dimesh D'Souza's book, but rather to explore a question that is miplicit in the PC debate but rarely addressed directly. Everyone writes as if universal tolerance were a virtue, but everyone also seenis to assuine that there are ideas and expressions that a university should not tolerate, or at least should not encourage. Sone, like Katharine Bartlett, will say that racist and sexist reniarks are out of place in the classroom, and assume that the offended wonien and minorities are the proper judges of what is racist and sexist. Others, like Dinesh D'Souza, will deplore the excesses of multiculturalism, insisting that umiversities should not give writers like Franz Fanon and Rigoberta Menchu an undeserved nitellectual status by placing their writing in survey courses that used to be devoted to the likes of Plato, Milton, and Rawls. The real dispute is not so much about tolerance as it is about what ideas a university ought to value. Is it more iniportant for students to learn to appreciate John Milton's excellence as a poet or to deplore his views on the role of wonen? Should an instructor feel free to defend Milton's opmions on women or other subjects, including theology? Is Rawls an important thinker and Fanon a mere propagandist, or might it be the other way around? Above all, who ought to have authority to decide questions like these?

I agree with Katharine Bartlett that we ought to have a genuine debate about academic quality and diversity that challenges perspectives that have been taken for granted in the university and society. As an opening move in that debate-with the purpose more of sparking further discussion than of resolving the ponits in dispute-I offer two true stories. Let's see what they tell us about what may and niay not be said in the conteniporary university.

\section{I}

\section{The CREationist ${ }^{10}$}

Phillip Bishop teaches classes in exercise physiology to graduate and undergraduate students in the College of Education at the University of

7. Id.

8. Id.

9. Id.

10. Except when otherwise noted, the source for the facts relating to the "creationist" story is the opinion by Judge Guin in Bishop v. Aronov, 732 F. Supp. 1562 (N.D. Ala. 1990) [hereinafter 
Alabama. Like many other college teachers, he considers it appropriate to tell his students something about himself and what he values. In his case, this personal disclosure involved saying that he believes that "God came to earth in the form of Jesus Christ and he has something to tell us about life which is crucial to success and happiness." 11 Because of this belief, Bishop prefers to invest his time in people rather than in publishing "a stack of technical papers." 12 He presented this view as his own "bias" and told students that "[i]f that is not your bias, that is fine."13 He also urged students to keep in mind that whatever he said probably reflected his Christian bias and urged them to tell him if his behavior fell short of his Christian ideals. ${ }^{14}$

Courts that later reviewed his conduct agreed that Bishop was otherwise very restrained. "He never engaged in prayer, read passages froin the Bible, handed out religious tracts,"15 or arranged for guest lectures on any religious topic during class. On the other hand, Bishop made no secret of his skepticism about the orthodox doctrine that the human body evolved by purely naturalistic and material processes such as randoin mutation and natural selection. He did not discourse on this subject in class, but he did invite students and others to a voluntary, after-hours meeting at which he lectured on "Evidences of God in Human Physiology."16 Bishop is not a Biblical literalist or opponent of evolution in some broad sense, but he behieves that materialistic forces alone could not have created the wonderfully complex organs of the human body.

The head of Bishop's academic unit, Dr. Westerfield, later testified that students (whose names he could not renieniber) coniplained about Bishop's statenients and the optional lectures. ${ }^{17}$ Dr. Westerfield hiniself worried that Bishop's statements might hurt the University's acadenic reputation, because "other professional colleagues around the nation consider this the 'Bible belt' and [think] that . . a lot of this type of

Bishop I, rev'd, 926 F.2d 1066 (11th Cir. 1991), cert. denied, 112 S. Ct. 3026 (1992). Although the Court of Appeals reversed Judge Guin's legal conclusions, it adopted his findings of fact, which were based upon stipulations and undisputed affidavits. See Bishop v. Aronov, 926 F.2d 1066, 1068 (11th Cir. 1991) [hereinafter Bishop II], cert. denied, 112 S. Ct. 3026 (1992). Professor Michael McConnell of the University of Chicago Law School filed a petition for certiorari in the case which refers to some other details from the undisputed record that are not mentioned in the district court and court of appeals opinions. See Petition for a Writ of Certiorari at 2-9, filed sub nom. Bishop v. Delchamps, 112 S. Ct. 294 (1991) (No. 91-286), cert. denied, 112 S. Ct. 3026 (1992) [hereinafter Delchamps Petition].

11. Bishop II, 926 F.2d at 1068.

12. Id.

13. Id.

14. Id.

15. Bishop I, 732 F. Supp. at 1563.

16. Id. at 1564 .

17. The facts in this paragraph are taken from the undisputed record in the case as summarized by Professor Michael McConnell in Delchamps Petition, supra note 10, at 2-9. 
activity goes on in the University." 18 He shared his anxiety with the Dean of the School of Education, and the two went to see the University counsel to decide whether Bishop's reniarks amounted to an unconstitutional establishment of religion. Counsel assunied that what a state university professor says $\dot{\mathrm{n}} 1$ a classroom is tantaniount to an act of state government, and so is governed by the famous three-part test of Lemon $v$. Kurtzman. ${ }^{19}$ Applying that standard, counsel thought the University had a duty to "control this kind of activity"20 because Bishop's remarks had no secular purpose and created an excessive entanglenient between government and rehigion. ${ }^{21}$

Westerfield then ordered Bishop not only to cease referring to his rehigious behiefs during class time but also to discontinue "the optional classes where a 'Christian perspective' of an academic topic is dehiered." 22 The University's rationale for forbiddimg even after-hours discussions of this nature was that students might feel coerced to agree with Bishop's rehgion in hopes of gaining soine favorable treatnient. ${ }^{23}$

Bishop challenged the restrictions in federal court, with imitial success. The district court observed that the University's restrictions were auned not at coercive speech, or irrelevant speech, but only at religious speech. According to the opimion:

Nunerous undisputed affidavits filed indicate University policy does not prohibit faculty inembers from engaging in non-religious classroom speech involving personal views on other subjects. Sucl discussions are the norm used to establish rapport between faculty and students. There is no University policy attempting to control the statements of faculty neenbers as long as they do their job. Nor is there a University policy prohibiting faculty inembers from organizing after-class meetings if discussions are not from a religious perspective. The University lias no policy proscribing professor involvement in extracurricular academic discussions witl students. ${ }^{24}$

The district court held that a policy excluding only religious expres-

18. Id. at 6.

19. In Lemon v. Kurtzman, 403 U.S. 602 (1971), the Supreme Court set out a famous threepart test for determining whether a state statute is consistent with the First Amendment's Establishment Clause. "First, the statute must have a secular legislative purpose; second, its principal or primary effect must be one that neither advances nor inhibits religion; finally, the statute must not foster 'an excessive government entanglement with rehigion.' " Id. at 612-13 (citations omitted).

20. Delchamps Petition, supra note 10, at 6 .

21. See Bishop I, 732 F. Supp. at 1564.

22. Id. (quoting the disciplinary memorandum sent by Westerfield to Bishop).

23. See id. Bishop used a blind grading system, and so in theory the student's identity would have no effect on grading. The district court conditioned its approval of Bishop's practices on the requirement that he continue to use a blind grading system. See id. at 1569 . Of course, no similar requirement was imposed upon professors who express personal opinions of other kinds that students might also be tempted to mimic in order to get a good grade.

24. Id. at 1564 . 
sion from the classroom is unconstitutional under Widmar v. Vincent. ${ }^{25}$ In Widmar, the Supreme Court held that a state university must allow religious student groups to use campus facilities on the same terms as other student groups, on the theory that the First Amendment prohibits discrimination against speech on the basis of its religious content. ${ }^{26}$

A panel of the Court of Appeals for the Eleventh Circuit disagreed, and unanimously reversed the district court's judgment. ${ }^{27}$ The opinion by Judge Gibson ${ }^{28}$ said that the relevant Supreme Court precedent was not Widmar but Hazelwood School District v. Kuhlmeier. ${ }^{29}$ Kuhlmeier liad held that a high school primcipal may censor arguably offensive material from the school newspaper. ${ }^{30}$ Like a high school newspaper, reasoned Judge Gibson's opinion, the university classroom is not an "open forum" but rather a restricted venue dedicated to a specific educational purpose. ${ }^{31}$ To carry out that purpose, university administrators niay exercise "editorial control over the style and content of student [or professor] speech in school-sponsored expressive activities so long as their actions are reasonably related to legitimate pedagogical concerns." 32 This broad authority apparently applies to professorial speech of any kind, whether rehigious or not.

That a professor in a university classroom has no greater freedonı of expression than the student editor of a high school newspaper, and much less than a high school student who wears an armband protesting the Vietnam War, ${ }^{33}$ might be surprising to those who recall the strong statements of support for academic freedom in Supreme Court opinions of the

25. See id. at 1565 (citing Widmar v. Vincent, 454 U.S. 263 (1981)).

26. See Widmar v. Vincent, 454 U.S. 263, 276 (1981). Although the district court was apparently unaware of it, another state unversity had followed the Widmar principle in a controversy very similar to the Bishop case. University of Georgia Professor Henry F. Schaefer, an internationally famous quantum chemist, gave voluntary, after-hours lectures on campus for students at which he explained his Christian faith and his doubts about Darwinism. Other faculty nembers demanded that the University stop allowing Schaefer to use its facilities for religious speech, but the University's President ruled that Schaefer had freedom to express his thoughts on campus property since the lectures were not university-sponsored. The ruling was not challenged in court, and Schaefer has contimued to speak freely. See Motion for Leave to File Brief Amici Curiae and Brief of Dr. Henry F. Schaefer III, Dr. Gerald R. Bergman, Dr. Clinton H. Graves, and Dr. Byron R. Johnson as Amici Curiae in Support of the Petition for Certiorari at 2, Bishop v. Delchamps, 60 U.S.L.W. 3292 (U.S. Oct. 15, 1991) (No. 91-286), cert. denied, 112 S. Ct. 3026 (1992).

27. Bishop II, 926 F.2d at 1078.

28. Senior Circuit Judge Floyd R. Gibson of the Eighth Circuit was sitting on the Eleventh Circuit by designation.

29. 484 U.S. 260 (1988).

30. See id. at 276.

31. See Bishop II, 926 F.2d at 1071.

32. Id. at 1074 (quoting Kuhlmeier, 484 U.S. at 273) (bracketed phrase "[or professor]" added in Bishop $I I$ opinion).

33. In Tinker v. Des Moines Independent Community School District, 393 U.S. 503, 514 (1969), the Supreme Court held that school authorities could not forbid a student to wear a black armband (protesting the Vietnam War) to school, absent a showlng that the forbidden conduct 
loyalty-oath era. For example, Justice Brennan's opinion for the Court in Keyishian v. Board of Regents said:

Our Nation is deeply committed to safeguarding academic freedoin, which is of transcendent value to all of us and not merely to the teachers concerned. That freedom is therefore a special concern of the First Amendment, which does not tolerate laws that cast a pall of orthodoxy over the classroom. ${ }^{34}$

Judge Gibson's opinion actually quoted that statement, but only to hold that it "cannot be extrapolated to deny schools command of their own courses," because "[f]ederal judges should not be ersatz deans or educators." ${ }^{35}$ Academic freedom is protected not by the judiciary, wrote Judge Gibson, but by the presumed sensitivity of administrators to conditions in the academic labor market. "Umiversity officials are undoubtedly aware that quality faculty menibers will be hard to attract and retain if they are to be shackled in much of what they do."36

The district court had been particularly mipressed by the selectivity of the University's policy, which did not exclude the subject of rehigion, but permitted only one kind of opinion on that subject to be discussed. The pohicy "would allow groups of young philosophers to meet to discuss their skepticism that a Suprenie Being exists, or a group of political scientists to meet to debate the accuracy of the view that religion is the 'opium of the people." "37 The district judge noted that the University even offers courses in rehigion and theology, but prohibits instructors in those courses (but not in other subjects) from stating their personal views about the subjects they teach. ${ }^{38}$ How can the First Amendment permit,

would substantially interfere with the work of the school or impinge upon the rights of other students.

34. 385 U.S. 589, 603 (1967).

35. Bishop II, 926 F.2d at 1075.

36. Id. The United States District Court for the Southern District of New York took a different position on the judicial protection of academic freedom in Levin v. Harleston, $770 \mathrm{~F}$. Supp. 895 (S.D.N.Y. 1991). Michael Levin is a philosophy professor at the City College of the City University of New York who has published various provocative statements on racial issues, in particular claiming that "on average, blacks are significantly less intelligent than whites." Id. at 902. As a consequence his classes were disrupted by demonstrators, the college president appointed a committee to investigate his writings witl a view to possible disciplinary action, and administrators wrote to students in his introductory philosophy class that they would create a "shadow section" for students who wished to take the course but avoid Professor Levin. Id. at 903-08. District Judge Conboy leld that appointment of the investigating committee and the institution of "shadow sections" violated Levin's free speech and tenure rights. See id. at 919-25. The court permanently enjoined the college from investigating Levin's writings and also ordered the administrators to take rcasonable steps to prevent disruption of his classes. See id. at 927. The Levin case is distinguishable from the cases discussed in this Review Essay, lowever, because it did not involve the autlority of academic administrators to control what a professor says in the classroom. Levin apparently did not introduce his views on racial issues into his plilosophy courses. The controversy involved solely his out-of-class writings. See generally id. at 899-903.

37. Bishop I, 732 F. Supp. at 1568 (quoting Widmar v. Vincent, 454 U.S. 263, 281 (1981) (Stevens, J., concurring)).

38. See id. at 1567-68. 
much less require, that the content of speech be so selectively restricted?

The court of appeals answered that selectivity was entirely justified, because Bishop's viewpoint was particularly likely to cause "apprehension":

[T] he University asks only that [Bishop] separate his personal and professional beliefs and that he not impart the former to his students during "instructional time" or under the guise of the courses he teaches in socalled optional classes.

... Dr. Bishop has tried to inake much of the fact that the University has no policy for limiting the speech of its professors only to their subject areas. ... [He] has filed numerous affidavits by other instructors at the University describing their extracurricular speech in the classroom as efforts to reach out to students. These attempts at professor-student affinity are laudable. But plainly soine topics understandably produce more apprehension than coinfort in students. Just as women students would find no comfort in an openly sexist instructor, an Islamic or Jewish student will not likely savor the Christian bias that Dr. Bishop professes .... There is no suggestion that any other professor has produced student complaints or struck constitutional chords. ${ }^{39}$

Although the court of appeals insisted that it was for administrators to decide which opinions were too unsettling to be uttered in the classroom, the administrators themselves were under the inipression that they were obligated to silence Bishop on legal grounds. In court, the Unversity defended its position on the theory that Bishop's remarks violated the First Amendment's Establishment Clause. ${ }^{40}$ The court of appeals did not formally decide the Establishment Clause question, but left hittle doubt as to what its decision would have been. "Dr. Bishop's optional class was particularly suspect," remarked the opinion, because the "creation/design aspect of his lecture could have lent itself to an analysis as found in Edwards v. Aguillard, 482 U.S. 578 (1987)."41

If the First Amendment forbids a state university to allow any mention of creation even in voluntary, after-class sessions, then freedom of expression must be a very subtle doctrine. If the legality of unorthodox speech turns on whether it has any educational value, then it may conceivably benefit students to hear an argument for an opinion that is pervasively denigrated in the rest of the curriculum. Professor Bishop holds such a disfavored opimion about his subject, the human body. He thinks that the body was produced by an intelligent designer rather than by an unguided naturalistic process. He therefore rejects the neo-Darwinistic

39. Bishop II, 926 F.2d at $1071-72$ (citation omitted).

40. Bishop I, 732 F. Supp. at 1565.

41. Bishop II, 926 F.2d at 1077. Edwards v. Aguillard held unconstitutional a Louisiana statute requiring balanced treatment in science classes for "creation-science" and "evolutionscience" on the ground that the Legislature's purpose "was clearly to advance the religious viewpoint that a supernatural being created humankind." 482 U.S. at 591. 
theory of evolution, which is taught in most universities as fact. According to Darwinisin, the appearance of intelligent design in biology is nisleading. No designer was involved, because scientific investigation has established that a conibination of randonı genetic changes and natural selection actually crafted the biological wonders that creationists have cited to support the argument fron design. As George Gaylord Sinipson, one of the niost authoritative proponents of neo-Darwinisn1, put the point in his book The Meaning of Evolution: "Man is the result of a purposeless and natural process that did not have him in mind."42

Apparently, a statenient like Simpson's is professional, scientific, and secular. To contradict that statenient, on the other hand, is private, unscientific, and nonsecular. The state practices neutrahty on rehious questions by privileging statements hike Sinipson's and relegating opposing statenients to the closet of private life. Here is how the court of appeals explained the matter:

Dr. Bishop has expressed certain personal (perhaps even professional) opinions about his work that happen to have a religious source. The University has concluded that those opinions should not be represented in the courses he teaches at the University. The University has not suggested that Dr. Bishop cannot hold his particular views; express then1, on his own tinee, far and wide and to whomever will listen; or write and publish, no doubt authoritatively, on them; nor could it so prohibit hini. The University has simply said that he nay not discuss his rehigious beliefs or opinions under the guise of University courses. ${ }^{43}$

But why forbid free discussion of "perhaps even professional" opinions on a controversial subject that is pervasively addressed in the University's curriculunt? Why can the professor write, "no doubt authoritatively," but not talk? Would the University-or the Constitution-forbid him to assign those writings to a class that also considered the writings of George Gaylord Simpson?

At this point I should declare a personal interest. I ant the author of a book, Darwin on Trial, ${ }^{44}$ which supports Bishop's heretical opinion. In the book I argue that the neo-Darwinist theory is a inyth, and specifically that an impartial interpretation of the scientific evidence does not support the claim that natural selection has the vast creative power that Darwinists claim for it. What is worse, I propose that unbiased people, including scientists, should "consider the possibility that life is what it so evidently seenis to be, the product of creative intelligence." 45 In the opening chapter, I disclose niy personal religious viewpoint, "because I do not exempt inyself from the general rule that bias must be acknowl-

42. George G. Simpson, The Meaning of Evolution 345 (rev. ed. 1967).

43. Bishop II, 926 F.2d at 1076 (footnote omitted).

44. Phillip E. Johnson, Darwin on Trial (1991).

45. Id. at 110 . 
edged and examined." 46 I have even assigned some of my writing on this subject to law students at the University of California. Have I violated all three prongs of the Lemon test?

Judge Gibson's opinion becomes much easier to understand if we infer that he regarded Bishop's opinions as absurd and offensive, and therefore deserving of censorship, but did not want to say so directly. Implicit in the opinion is a thinly veiled contempt that comes out unmistakably in the choice of language. Dishonesty is implied in that Bishop presents his notions "under the guise" of legitimate course work or in "so-called" optional classes. Only a tin ear could miss the sarcasm in the condescending remark that Bishop may publish "no doubt authoritative[]" opinions that the University properly forbids him to utter in class. Finally, the opinion implies that Bishop's acknowledgment of "Christian bias" was as offensive as if he had proudly declared hinself to be a bigot.

If that view of Christianity is widespread in elite university and judicial circles, it is easy to see why Bishop was such an embarrassment to administrators concerned about their place in the academic pecking order. Agnostic fashion had to be enforced without departing from the law's famous neutrality on religious matters, of course. The tinehonored way of doing that sort of thing is to eniploy the religious/secular dichotomy, which (ever so respectfully) silences the disfavored opinion in the name of First Amendment freedoms.

II

\section{THE SOCIOBIOLOGIST ${ }^{47}$}

Vinicent Sarich is a physical antliropologist at Berkeley who pioneered in the use of molecular evidence to measure the relative degree of biochemical similarity between hunians and various other aninials. Employing the "molecular clock hypothesis," Sarich (with Berkeley biochenist Allan Wilson) estiniated that the last cominon ancestor of chimps and humans lived much nore recently than had previously been thought. After a period of fierce resistance fron fossil experts, the Wilson/Saricl date and inethodology became widely accepted. The accomphishment established Sarich's reputation as a major figure in huinan evolution studies and as a formidable controversialist.

Sarich came to the attention of a different audience when he publisled a paper in the California Monthly (Berkeley's alumni magazine) with the provocative title Making Racism Official at Cal. ${ }^{48}$ His thesis was that Berkeley's undergraduate adnissions policies systeniatically dis-

46. Id. at 14 .

47. Except where otherwise indicated, the source for information about Vincent Sarich and the class disruption at Berkeley is Paul Selvin, The Raging Bull of Berkeley, 251 SCIENCE 368 (1991).

48. Vincent Sarich, Making Racism Official at Cal, CAL. MoNTHLY, Sept. 1990, at 17. 
criminate against whites. Whites comprise about $60 \%$ of high school graduates and $65 \%$ of those academically eligible for admission to the University of California, but they comprised only 34\% of fall 1989 freshman registrants at Berkeley. For Asians the corresponding numbers were $8 \%, 20 \%$, and $23 \%$; for Hispanics, $20 \%, 7 \%$, and $23 \%$; and for Blacks, $8 \%, 2.5 \%$, and $12 \%{ }^{49}$ In plain language, Asians were hugely overrepresented in the freshman class in coinparison to their share of the general population; Hispanics and Blacks were hugely overrepresented in comparison to their representation in the population deeined academically qualified on the basis of high school performance; and Whites were underrepresented in comparison to both their share of the general population and of the population deemed academically qualified.

The social and political factors that produced these figures are no mystery. Like other umversities, Berkeley lias been under strong moral and legal pressure to increase the percentage of Black and Hispanic students at least to their level in the population. At the sane time, AsianAmerican groups liave vigorously and effectively protested the "discrimination" Berkeley has practiced by not admitting Asians on the basis of their academic performance. This mix of pressures has produced a tacit policy of population parity (generously measured) for Blacks and Hispanics, and admission by grades and test scores for Asians. Somebody has to pay the price. ${ }^{50}$

Saricli argued that the admissions policy had created a two-tiered student body, "separable on racial/ethnic grounds, and increasingly divergent from one anotlier academically, socially, and in etlos."51 The consequences include increased racial tension, discouragement of the pursuit of excellence among all groups, and the decay of a great public educational institution. Sarich concluded that the costs of Berkeley's racial policy "are obvious and large; the benefits, if any, difficult to perceive, and certainly undocumented."52 Dinesh D'Souza made similar arguments, using Berkeley as the prime exainple of race-based admissions policies..$^{53}$

Sarich provoked lostility not just because lie concluded that the costs of the university's admissions policy outweigh its benefits but because he insisted publicly tliat real academic costs exist. The univer-

49. Id.

50. Berkeley Chancellor Ira M. Heyman apologized publicly in April 1989 for pursuing admissions policies aimed at increasing minority representation that had the unintended effect of disadvantaging Asians who obtained high scores on aptitude tests and high grades in high school. Berkeley promised to stop discriminating against high-aptitude Asians without otherwise abandoning its goal of ensuring racial balance in the student body. See DINESH D'SouzA, ILLIBERAL EDUCATION 30 \& n.30 (1991) [hereinafter cited by page number].

51. Sarich, supra note 48 , at 18 .

52. Id.

53. See pp. 24-58 (detailing admissions policies and their effects on individual students and the campus at large). 
sity's official position is that policies aimed at achieving (racial) diversity do not sacrifice (academic) excellence. ${ }^{54}$ Berkeley officials in particular insist that the mean Scholastic Aptitude Test score for entering freshinen has steadily increased, arguing that this figure establishes that academic quality and racial diversity have improved in tandem. ${ }^{55}$ Advocacy groups that support affirmative action are still more vehenent in disputing any suggestion that less qualified students are being admitted to meet racial targets. Anyone who wants a relatively peaceful life in Berkeley does not seek occasions for asserting a different interpretation of the facts.

Sarich's admission paper did not spark that genuine debate over acadeinic quality and diversity desired by Katharine Bartlett. ${ }^{56}$ Instead, it led to a retaliatory deinonstration directed at disrupting his teaching in the introductory anthropology course. ${ }^{57}$ As a scientist who inade his reputation studying molecules rather than tribes, and as a political conservative (by umiversity standards), Sarich is hardly in the inainstream of anthropology. Moreover, he teaches an "advocacy course," in which students get a heavy dose of the Sarich viewpoint. In a nutshell, the Sarich viewpoint is that the logic of evolutionary biology should be

54. See, e.g., Letter from Vincent Sarich, Professor, University of California at Berkeley, to William French Smith, Regent, University of California 3 (Apr. 4, 1990) (on file with author) (quoting university administration officials as having said "these achievements are not at the expense of quality" and "everyone admitted to the school is 'University of California-eligible" ").

55. See Committee on Admissions and Enrollment, Freshman Admissions at Berkeley: A Policy for the 1990's and Beyond (Karabel Report) (May 1989) (committee report, on file with author). The Karabel Report states that "[t]he great accomplishment of the overall admissions policy has, in our view, been its capacity to continue the process of diversification of Berkeley's student body at the same time it has maintained and even raised the academic level of the freshman class." Id. at 26, quoted in Letter from Vincent Sarich to William French Smith, supra note 54, at 5. Sarich's article in the California Monthly attributed the rise in mean SAT scores to a continuing rise in scores of admitted whites and Asians (about $60 \%$ of admittees) during the 1980s. In other words, the rise in mean academic indicator scores does not contradict Sarich's claim that the class is increasingly coinposed of distinct groups whose academic qualifications barely overlap. On the other hand, former Berkeley Chancellor Ira M. Heyman in a letter of response noted among other things that Sarich presented no evidence about how well various categories of students perform oncc admitted. See Letter from Ira M. Heyman, Chancellor, University of California at Berkeley, to William French Smith, Regent, Umiversity of California S (May 9, 1990) (on file with author). Heyman cited figures to support the conclusion that "the GPAs of underrepresented students are much higher than one would expeet from Professor Sarich's observations." Id.

56. See supra text accompanying notes 5-9. Ideally, such a debate would not be limited to the relatively sterile issue of whether efforts at racial diversity in admissions are in principle a good thing. In the contemporary social elimate an institution like the University of California simply must use its resources for the benefit of all the major racial and ethnic groups of the state. The use of race as a factor in admissions is like the use of medicine: taken for the right purpose and in the right amount, medicine alleviates illness without devastating side effects. To determine the right medicine and the right dosage, it is necessary to discuss honestly the underlying illness and the actual effects of the treatment.

57. See T. Christian Miller, Students Clash in Anthro, The Daily Californian, Nov. 8, 1990 , at 1 . 
extended to questions of human nature and social policy. ${ }^{58}$ This approach is highly controversial because the pohtical left regards anything reminiscent of "social Darwinism" as pseudoscientific propaganda for the status quo. Although Sarich's teaching was popular with many students, there were also continual complaints, articulated especially in courses in Women's Studies. ${ }^{59}$ The pubhcity given the adınissions paper suggested to these critics that Sarich's philosophy might have tangible political consequences. Since Anthropology I is a required course for majors in a field that appeals to many students having intense interests in the politics of race and gender, the mix was explosive.

The explosion came in November 1990, when more than fifty students mvaded Sarich's classroom to deinonstrate against his "racist, sexist, and homophobic" opinions. The opinions in question were culled froin the adinissions paper and froin lecture transcripts that Sarich made available to students as a study guide. The most frequently quoted statement was Sarich's comment in the adinissions paper that excellence and diversity are at cross purposes because "unfortunately, the levels of qualification, preparation, or inotivation are not randomly distributed with respect to race and ethnicity." 60 Sarich had added that he attributed relatively poor acadeinic performance by Blacks and Hispamics to cultural influences, not genetic differences, but this inportant qualification did not seem to initigate the offense and was subsequently ignored.

Sarich had also said in his lectures that huinan brain size steadily increased as human intelligence evolved. A correlation of brain size and intelligence in the reniote past is uncontroversial and probably an essen-

58. Professor Sarich generously provided me with transcripts of his Anthropology I lectures and other material relating to the course content. His central thesis is that, while most educated people agree that Darwinian evolution is responsible for the human body, they refuse to acknowledge the implications of Darwinian theory in the area of human behavior, politics, and ethics. Most left/liberal intellectuals, including even leading evolutionary biologists, are essentially "creationists" when it comes to human affairs. They have merely substituted human society for God as the creator of human nature. In other words, they deny that evolution has formed human nature im important ways and imagine instead that our nature is a blank slate upon which culture can write at will.

Specifically, these humanistic creationists refuse to acknowledge that human in equality rather than equality is the norm, because "the evolutionary process continues to run on variation and that variation must be functionally significant." Vincent Sarich, Notes, Lecture No. 3, at 1 (Aug. 29, 1990) (on file with author). This leads them into absurdities such as imagining that male/female behavioral differences have no biological bases, or that it is possible to achieve an artificial equality of outcomes by social coercion. Such utopian projects end in unfreedom (and also inequality) because they ignore the constraints imposed by evolution. Specific applications of this general theme are addressed throughout the course.

59. Sarich's teaching materials include a paper that was written in 1986 by a freshman woman who was taking Women's Studies 10 and Anthropology I (with Sarich) at the same time and naively wrote a paper for the former course defending Sarich against charges of sexism. The teaching assistant who graded the paper could not restrain her fury that anyone would say anything good about Sarich and covered the paper with heavy-handed political comments. See Vincent Sarich, Lecture Materials 27-34 (1990) (on file with author).

60. See, e.g., Miller, supra note 57, at 11 (quoting Sarich, supra note 48, at 18). 
tial premise of the theory that humans evolved from small-brained apes, ${ }^{61}$ but Sarich offended contemporary sensitivities by arguing that the correlation might still exist. ${ }^{62} \mathrm{He}$ went so far as to suggest that it would be appropriate to conduct research on whether differences in male and female mental capabilities are related to the smaller average size of women's brams. ${ }^{63}$ Finally, Sarich had said in his lectures that homosexuality in humans is culturally rare and not genetically determined because natural selection would not foster a gene for a nonreproductive sexual

\section{Here is what Darwin himself wrote on the subject:}

As the various mental faculties were gradually developed, the brain would almost certainly have become larger. No one, I presume, doubts that the large size of the brain in man, relatively to his body, in comparison with that of the gorilla or orang, is closely connected with his higher mental powers.... On the other hand, no one supposes that the intellect of any two animals or of any two men can be accurately gauged by the cubic contents of their skulls....

The belief that there exists in man some close relation between the size of the brain and the development of the intellectual faculties is supported by the comparison of the skulls of savage and civilised races, of ancient and modern people, and by the analogy of the whole vertebrate series.

Charles Darwin, The Descent of Man 145-46 (photo reprint, Princeton University Press 1981) (1871).

62. In one lecture Sarich made his point about brain size with a pungent review of STEPHEN J.

GOULD, THE MISMEASURE OF MAN (1981):

This book received the Pulitzer Prize and was spoken of approvingly by just about everyone except Professor Sarich who thinks that the book is mostly nonsense. It is particularly nonsensical in its extensive castigation of his professional ancestors in the 19th and early 20th centuries who were fascinated with the idea [of] variation in brain size of human beings and its significance. These individuals measured heads both externally and (after death) internally.... Gould spends about half of his book denigrating this activity as at best useless and at worst intensively racist and sexist. ... [1] fou read only that book ... you would never know that the human brain had increased (tripled) in size over the last [two] million years. There is not a hint in that book that that happened. Why? Professor Sarich thinks that that fact is not mentioned because the only way that the human brain could have increased in size over time is if somehow larger brains [conferred] ... fitness on their possessors. If they conferred greater fitness on their possessors in the past, then they would also (presumably) do so in the present. This would invalidate the entire thesis of Gould's book.

Vincent Sarich, Notes, Lecture No. 16, at 4 (Oct. 3, 1990) (on file with author) (significant typographical errors in original transcript corrected by author).

63. Offensive or not, studies of male/female differences in brain size and structure are very much in the scientific mainstream. For example, a 1991 article in Science by Ann Gibbons observes that:

[T]here is now a solid body of data indicating sex differences in the brains of almost every mammalian family examined so far: rodents, birds, monkeys, and-most recently and most intriguingly - human beings... . Men's brains are on average larger than women's by $15 \%$ - about twice the difference in average body size between men and women.

Ann Gibbons, The Brain as "Sexual Organ," 253 SCIENCE 957, $957-58$ (1991). Attempts to explain behavioral differences between men and women on the basis of brain anatomy are controversial, but researchers "speculate that [brain differences] have roots in strong evolutionary pressures on the sexes during prehistory when the brain was expanding rapidly." Id. at 958 . A companion article by Constance Holden began with the observation that "a large body of evidence, accumulated over many decades, suggest[s] that there are some differences in cognition and perception between men and women." Constance Holden, Is "Gender Gap" Narrowing?, 253 ScIENCE 959, 959 (1991). The subject is "something of a political minefield," however, and all specific claims are disputed and doubtful. Id. 


\section{orientation. ${ }^{64}$}

The demonstration was resisted by many of the students actually enrolled in the class, ${ }^{65}$ who defended Sarich (or at least their right to hear him teach) vigorously. The point at issue between the enrolled students and the demonstrators was nicely captured in an exchange reported in the campus disciplinary report: ${ }^{66}$ One student yelled, "How can you argue about his teachings if you don't really know what he says?"67 to which a demonstrator responded, "How can we have intelligent discussion if he doesn't beheve we belong in school?"68 The demonstrators denounced minority students in the class as traitors for listening to Sarich. A teaching assistant tried to mollify the demonstrators by proposing a debate, but they shouted down the invitation, with one remarking that "FDR wouldn't debate Hitler."69 There was no physical violence, but the uproar and distraction finally forced Sarich to give up his attempt to finish the class.

Berkeley's newly installed Chancellor Chang-Lin Tien issued a statement saymg that the disruption would be investigated with an eye towards disciplinary action, but also that there would be an investigation of Sarich's teaching if allegations of discriminatory remarks were made in a proper manner. Members of the leaderless Anthropology

64. The Sarich viewpoint on homosexuality is that heterosexuality promotes reproduction, and therefore is more natural in evolutionary terms. Homosexuality is therefore unlikely to have a genetic cause. In other cultures it is rare as an exclusive adult predisposition, although adolescent homosexual experimentation is common. Sarich explained contemporary male homosexuality as growing out of the fact that some males are more inclined to the feminine side of the spectrum of male/female differences. Males having relatively more feminine emotional natures might feel less need to complement themselves with a heterosexual relationship, and might experience greater difficulty in fulfilling culturally imposed models of masculine behavior. In most cultures adolescents tend to grow out of homosexual tendencies because "[s]ocial completeness as an adult requires complementation," and "[i]t is set up evolutionarily and biologically that that complementation is set up with an individual of the opposite sex." Vincent Sarich, Notes, Lecture No. 16, at 1 (Oct. 3, 1990) (on file with author).

65. See Miller, supra note 57 , at 11 .

66. The source for the facts related in this paragraph is the unpublished report of Alan T. Kolling, the Administrative Analyst who officially investigated the disruption. See Report of Alan T. Kolling, Principal Administrative Analyst, University of Califoruia at Berkeley, to Francisco J. Hernandez, Dean of Student Life, University of Califoruia at Berkeley (Feb. 26, 1991) (on file with author) [hereinafter Kolling].

67. Kolling, supra note 66 , at 3 . The Kolling report amplified this statement:

Interestingly, almost all of the students claimed to have some disagreement with Sarich and his teachings, and said they enjoyed challenging him in his optional study sections or during office hours. This was apparently one of the major reasons why the demonstrators won few converts in the class: the students taking the course felt that the demonstrators neither understood what Sarich said in class nor realized the extent to which they disagreed with his material. All seemed disappointed that the parties failed to engage in a debate because they were interested in knowing what the demonstrators really had to say and because they believed that Sarich was quite open to participating in such a debate.

Id. at 7 .
68. Id. at 3.
69. Id. at 5 . 
Department also took tentative steps in the direction of investigating Sarich. ${ }^{70}$ Faculty senate committees were horrified that responsible authorities reacted to a classroom disruption by proposing an investigation of the victim ${ }^{71}$ and issued statements deploring the demonstration as a violation of academic freedom. In the end the demonstrators received only meaningless warnings as pumshment, and nobody investigated Sarich.

The principal aftermath of the mcident was a public forum a month later, at which Sarich defended his views against criticism from other faculty members. On this occasion the diversity issue became entwined with an ongoing debate among Berkeley's biochemistry professors concerning the materialist reductionism that dominates this branch of science. Biochemistry Professor Richard Strohman complained that "the lay public is under the impression that DNA controls everything."72 Strohman threw cold water on this scientific hubris, implying that speculation about genetic causes of human behavior goes way beyond what science can establish.

Sarich defended his emphasis on the genetic role in human behavior by pointing out that most other anthropologists slight genetics and attribute everything to culture. He also added his own voice to the criticism of reductionism, complaining that "[s]cientists act like people are controlled by a puppeteer. . . . They tend to argue, 'Is the puppeteer your genes or is the puppeteer society?' You never hear about an individual's will." 73 The reason we never hear about it is that free will is a meaningless concept to a materialist reductionist, who (by definition) assumes that all events have material causes. If Sarich really nieans that people have the power to change their traits of character by an exercise of free will, then to that extent he is, by his own definition, a creationist. ${ }^{74}$

The ultimate judgment on Sarich from the anthropological left was delivered at the public forum by his departmental colleague, Professor Nancy Scheper-Hughes. Asserting the need to protect students froin

70. The Anthropology Department at Berkeley is so divided and opposed to hierarchy that it has no chairperson. The Vice-Chancellor advised the Department that the Academic Senate's Committee on Courses was the appropriate body to investigate complaints against teaching, much to the surprise of the Committee on Courses, which did nothing.

71. Experienced faculty members did not take seriously the Chancellor's promise to take disciplinary action against the demonstrators. It is notorious at Berkeley that threats of disciplinary action against demonstrations are so much hot air, because substantial punishment is never imposed. Students will not testify against demonstrators, and aggressive lawyers know how to stymie the overjudicialized campus disciplinary proceedings. When misdemeanor criminal charges are brought, Berkeley jurors will not convict. In some circumstances administrators might have a legal obligation to take reasonable steps to prevent disruption of classes, however. See supra note 36.

72. T. Christian Miller, Faculty Challenge Sarich, The DaILy Cal.1Fornian, Dec. 7, 1990, at 1.

73. Id. at 1.

74. See supra note 58. 
false teaching because of their "impressionable minds,"75 she dismissed Sarich's theories from the realin of science in precisely the language Sarich would use in speaking of creationisin: “[I]t isn't bad science, it isn't science at all." ${ }^{\prime 76}$ Professor Sarich, meet Professor Bishop.

\section{EPILOGUE}

The moral of iny stories is not that there are pressures to conform in the university. Of course there are such pressures, as there always were. A university is not Hyde Park Corner, where cranks of every description hold forth from their soap boxes. It is ineant to be a place where knowledge is gained through research and then transmitted in classrooms. It is also a place where ideas and ideologies are taken seriously, which implies that they may be expounded passionately. Expression of opinion is on the whole free in most universities, in the strictly formal sense that disciplinary action against either faculty or students for offensive statements is rare. This does not-mean, however, that all opinions or theories are treated equally. First, freedom of expression itself can be used against dissidents, in the form of protest demonstrations, hecklers, and strident editorials in campus newspapers. Students may apply political standards when rating the teaching quality of their professors on forms which administrators use in deciding who gets rehired or promoted.

The most inportant pressures towards conformity, however, arise from the very nature of the academic enterprise. Any academic institution endorses some fundamental doctrines that its ruling authorities consider to be true and works mightily to transmit these doctrines to the minds of students as knowledge. The Evolutionary Biology Department teaches that the Darwinian theory of evolution is true, not just that it appeals to soine people who speak for the interpretive coinmunity that calls itself "science." The liberal arts departments teach - or used to teach-that something called Western Civilization has a literary and intellectual tradition of umique excellence. Persons who are skilled at propagating knowledge are given good grades, graduate fellowships, and tenured professorships. Persons who try to advance beliefs that are con-

75. Miller, supra note 72 , at 1 .

76. Id. The official report by analyst Allan Kolling contains an interesting reference to this confrontation:

Many of the students who attended the . . . debate between Sarich and other anthropologists expressed anger at the way Sarich was treated by his colleagues, especially Nancy Scheper-Hughes. Some expressed admiration for Sarich's 'bravery' while at least one student felt that Scheper-Hughes' behavior at the forum was as 'disruptive' as some of that exhibited by the demonstrators. This particular student expressed some apprehension about testifying against demonstrators since faculty members had behaved in an equally outrageous manner towards Sarich and would not be held accountable. It bears repeating that many of these same students stressed their disagreement with Sarich's material during my interview.

Kolling, supra note 66 , at 7 . 
trary to received knowledge are considered to be ignorant, and so they face heavy discouragement. The established academic authorities consider it their duty to cure ignorance, not to reward it.

This encouragement of knowledge and discrimination against ignorance is proper and even inevitable in principle, but it may be oppressive in practice. Unconventional theories might be true, or at least stimulating, and they might offend by rousing the more conventional inembers of the umiversity community front their dogmatic slunibers. Wherever we find power, we also find prejudice. Aspiring scholars who consider themselves to be victims of prejudice are not necessarily helpless, however. If they have influence of one kind or another, they might persuade the university's ruling bodies to give thein acadenic departments of their own, in which they will have the power to decide what qualifies as knowledge and what should be disqualified as prejudice. If their influence grows, they might eventually be able to transform the university itself.

The battle to control the university's intellectual agenda is no recent innovation. For much of the mineteenth century niost universities were church-sponsored, and as such they did not willingly give a platform to atheists or sponsors of free love. Later in the nineteenth century, scientific naturalisin began to replace Christian theisin as the governing ideology. One consequence of this developinent was that Darwinian evolution acquired the status of knowledge, and students who did not accept it as such were classified as ignorant. That a professor of science would tell a class that he did not believe in naturalistic evolution becaine unthinkable, and a university that tolerated that sort of nonsense would have cause to fear a loss of academic status. This fear explains the determination of University of Alabama adıninistrators to exclude Phillip Bishop's inild dissent.

Ironically, the prestigious institutions to which the Alabama administrators looked for approval are theniselves in turmoil and possibly on the verge of another transformation in their governing philosophy. Scientific naturalism still reigns supreme among senior faculty and in the natural science departnients, but in the liberal arts and social sciences a relativistic pluralism is gaining ground. The historian Page Smith, whose description of the university's selective open-mindedness began this Review Essay, wrote that the nonscientific departnients in the recent past suffered fronı "physics envy." No inore. The newly fashionable postModernist nodel of knowledge is not based on scientific einpiricism, but on literary criticisn1, and its philosopher kings are Richard Rorty, Stanley Fish, and Jacques Derrida. Knowledge in this nodel is relative to culture, and no single picture of reality has absolute authority over rival cultural understandings.

As new groups have begun to assert themselves, the philosophy of cultural relativisnı has inade it easy to justify the institution of advocacy 
departments, in subjects like ethnic studies, women's studies, and now gay and lesbian studies. The premise of these departments is that the groups in question have been silenced and stigmatized, and therefore they need to find their own voices and assert their own theories of knowledge. This premise implies a certain homogeneity of ideological approach. One does not expect to find many professors of women's studies who favor restrictions on abortion, although many women take that position. Just as the Evolutionary Biology Department by definition rejects the creationist, women's studies by definition excludes the antifeminist.

The Sarich incident is an example of how a theory of knowledge that has wide support in the university can generate bitter conflict if it is taken to its logical conclusion before the wrong audience. The theory in question is that scientific mvestigation is the basis of all real knowledge and that science ought to be free to investigate all subjects. But what if the investigation seems to poimt in directions that many consider to be profoundly offensive? Is it a violation of academic freedom to discourage a professor from conducting research into the relationship between brain size and intelligence, or from trying to convince a class of undergraduates that such research is likely to lead to interesting and controversial conclusions? Scientific naturahism presupposes a fundamental distinction between fact and value, which imphes that the results of scientific research will not necessarily be pleasing to any group's cherished values, be they religious or pohtical. But the conclusions of scientific researchers inight be erroneous and might cause tangible harm before their error is exposed. Should a university community require its scientists to exercise restraint when dealing with sensitive subjects, in view of this potential for harm?

No one can answer such questions adequately in the abstract. They are especially difficult to answer in the context of a contemporary university, where the nature and even the very existence of objective knowledge is in question. If the university is dedicated both to the pursuit of knowledge and to the realization of equality, which goal has priority in the event of a conflict? The founding document of our national tradition states that "all men [we would now say all persons] are created equal." This means that, despite their differing abilities and attainments, all persons are of equal importance in the siglit of tleir creator, who is the author of values. Human equality in the Declaration of Independence sense is a sacred dogma, and as such it can never be discredited by any scientific discovery or rationalistic argument.

But suppose men and women are not created, and instead evolved by some haphazard process from aniinals. Suppose that dogmas exist no more, because the author of values has been exposed as an imposter and all persons must now decide for themselves whiat they will believe. On 
what foundation, then, can human equality rest? Is equality a fact everyone can see, a scientific hypothesis open for testing, or a story that appeals to certain kinds of listeners? It isn't easy to see how eitlier literary theory or unfettered scientific research into liuman capacities can be trusted to support the ideals of equality to which the contemporary university is formally dedicated. People still have their sacred dogmas, of course, even if they do not call them that. They just do not know what makes them sacred.

The status of human equality is not a puzzle for me. That is because I still believe that humamity was created, and therefore I understand that there are inoral axioins that take precedence over the temporarily alluring products of rationalistic disciplines. To me, the most interesting problem in pliilosopliy is how we are to recognize the axioms, so we know what to protect from the indiscriminate corrosiveness of skeptical analysis. It is a tougli problem, even when you understand low to ask the question. If you think you can build values on reason, and liave adopted a model of reason tliat consigns value judgments to the realin of subjective belief, you do not have a prayer. 